\title{
EXTRACELLULAR ALKALINE PHOSPHATASE FROM MANGROVE SOIL YEAST
}

\author{
Nur Hidayatul Alami*, Windasari Putri Septarina, Tania Pratiwi, M.P., N.D. Kuswytasari, \\ Enny Zulaika, and Maya Shovitri
}

\author{
Department of Biology, Institut Teknologi Sepuluh Nopember, Sukolilo, \\ Surabaya,60111,Indonesia,Office Phone/fax: +62 315963857 \\ *Corresponding author: phone number: +62 8133043 3930, \\ email: hidayatulalami@bio.its.ac.id
}

\begin{abstract}
Alkaline phosphatase is a widely used enzyme in research and industry. Yeast is one of a microbial group that has the potency to produce alkaline phosphatase. This study aims to screen yeast from mangrove in Surabaya's East Coast that produce f alkaline phosphatase and to optimize the production of these enzymes.Screening test includes the measurement of phosphate solubilization index and concentration of soluble phosphate. Yeast with potential of phosphate solubilization will be used to measured the enzyme activity and also further optimizedfor extracellular alkaline phosphatase production.Optimization was done by determining the incubation time and a variety of combinations of phosphate source and temperature. The incubation time was adjustedto 7 days. $\mathrm{Ca}_{3}\left(\mathrm{PO}_{4}\right)_{2}$ and $\mathrm{KH}_{2} \mathrm{PO}_{4}$ as the phosphate sourceand incubation temperature were adjusted to $29^{\circ} \mathrm{C}, 45^{\circ} \mathrm{C}$, and $55^{\circ} \mathrm{C}$. The results showed that isolates with the highest phosphate solubilization index were W1.1 and G3.2 (1.18 for W1.1 and1.15 for G3.2). Yeast with the ability to solubilize phosphate was assumed to be Candidagenus.W1.1 andG3.2 produced soluble phosphate in a concentration of 0.50 ppm and $0.77 \mathrm{ppm}$ at the 7th day respectively. Candida G3.2 has higher enzyme activity than Candida W1.1. Candida G3.2 has optimal production for 3 days incubation time with a combination of temperature $29{ }^{\circ} \mathrm{C}$ and $\mathrm{Ca}_{3}\left(\mathrm{PO}_{2}\right)_{2}$ as the phosphate source which caused 97.8 U/mL enzyme activity.
\end{abstract}

Keywords: alkaline phosphatase, enzyme activity, mangrove soil yeast 


\section{INTRODUCTION}

Yeast is widely used in industrial processes, such as the production of alcoholic beverages, food, fodder and synthesis of various metabolic products. The enzyme is one of the metabolic products that are often explored in the industry (Norouzian, 2008). Based on the adaptability of yeast in extreme environments, yeast from the marine area including mangrove area also has potential over other terrestrial yeasts, related with salt tolerance, enzyme production, and the production of ethanol and other fermentation processes (Kandasamy et al., 2012).

Yeast isolated from the marine area can produce extracellular hydrolytic enzymes (Chi et al., 2009). One of the hydrolytic enzymes is alkaline phosphatase. Alkaline phosphatase (orthophosphate monoester phosphohydrolases, EC 3.1.3.1) is metalloenzyme (Sasajima et al., 2010) which is responsible for breaking the phosphate group (dephosphorylation) of different types of molecules, including nucleotides, proteins, and alkaloids (Holander, 1971). As the name implies, alkaline phosphatase has optimal catalytic activity at alkaline $\mathrm{pH}$ (Rin et al., 2000). In various organisms, alkaline phosphatase has an important role in the process of transportation and phosphate metabolism (Fernandes et al., 2008).

Alkaline phosphatase is widely used in the fields of clinical diagnostics,and molecular biology as a quantitative measurement of biochemical markers in diseases, such as ELISA (Guo et al., 2018) () The importance of alkaline phosphatase in the field of medical science and molecular biology made alkaline phosphatase widely explored in the study of scientific and commercial interest (Muginova et al., 2007). Commercial alkaline phosphatase nowadays is extracted from the intestines of cattle and Escherichia coli (Sigma-Aldrich, 2013). Because of the expensive process of extracting enzymes from animals, publicperception in potential dangers of E. coli strains, and low adaptability of bacteria compared to yeast (Lambertz et al., 2014),yeast can be used as an alternative source for the production of alkaline phosphatase. 
Alami and Shovitri, (2015 has been obtained yeast from Surabaya East Coast region. However, those isolates have not been tested its potential in the production of alkaline phosphatase. Therefore, this study aimed to screen yeast from mangrove in Surabaya's East Coast that potential to produce alkaline phosphatase and to optimize the production of these enzymes.

\section{MATERIALS AND METHODS a. Subcultures of Yeast Isolates}

Yeast isolates collection of Microbiology and Biotechnology Laboratory, Biology Department,ITS, was subcultured on a slant YMEA (Yeast Malt Extract Agar) medium, and then was incubated for four days at room temperature.

\section{b. Measurement of Phosphate SolubilizationIndex}

Isolates were aseptically inoculated into a Petri dish containing Pikovskaya medium by spot inoculation method. The cultures were incubated at room temperature and observed the formation of a clear zone every 24 hoursfor 7 days. Yeast that potential in phosphate solubilization was indicated by clear zone formation around the colony (Kanti, 2006). Clear zone and the diameter of colonies counted every 24 hours for 7 days to obtain Phosphate Solubilization Index. To calculate SI (Solubilization Index) according to (Jena and Rath, 2013) used the following formula [1]where SI is solubilization index, $x_{1}$ is clear zone (cm), $x_{2}$ is the diameter of colonies (cm).

$$
S I=\frac{\mathrm{x} 1+\mathrm{x} 2}{\mathrm{x} 2}
$$

Two isolates with the best results from this test will be continued to the next step.

\section{c. Measurement of Soluble Phosphate Concentration \\ Phosphate solubilization test is} conducted to determine the strength of the isolates in dissolving phosphate, 2 isolates with the best result from the previous test were used in this test. Yeast suspension is done by taking some ose of yeast from YMEA slant to put in $100 \mathrm{~mL}$ of sterile physiological water to obtain $0.5 \mathrm{OD}$ at a wavelength of $600 \mathrm{~nm}$. About $6 \mathrm{~mL}$ of suspension was inserted into 8 pieces Erlenmayer which already contains $54 \mathrm{ml}$ of liquid 
Pikovskaya medium. The cultures were incubated at room temperature using a rotary shaker at $130 \mathrm{rpm}$. Phosphate levels were measured at each end of the incubation time, measurements were carried out after the culture was incubated for $0,1,2,3,4,5,6$, and 7 days. The culture medium was harvested and inoculated on YMEA with pour plate method to obtain the number of colonies of the yeast at each time of incubation. In addition, about 20 $\mathrm{ml}$ of culture is taken, then filtered using Whatman Paper No. 42 and centrifuged (4,000 rpm for 15 minutes) (Saraswati et al., 2007). About $3 \mathrm{~mL}$ of the supernatant was put into a test tube. Then added $0.5 \mathrm{~mL}$ of phosphate reagent and allowed to stand for 1 minute. The absorbance was measured at $\lambda 880 \mathrm{~nm}$. Measurements of soluble phosphate were done by interpolating the absorbance values on the standard curve.

\section{d. Quantitative Test of Alkaline Phosphatase by Yeast}

2 isolates from the previous step were tested quantitatively using a liquid medium Pikovskaya (Kapri and Tewari, 2010) which has a composition (g/ L):
0.500 yeast extract; glucose $10 ; \mathrm{Ca}_{3}$ $\left(\mathrm{PO}_{4}\right)_{2} \quad$ 5; $\left(\mathrm{NH}_{4}\right)_{2} \mathrm{SO}_{4} \quad 0.5 ; \mathrm{KCl} \quad 0.2 ;$ $\mathrm{MgSO}_{4}$ 0.1; MnSO4 0.0001; and $\mathrm{FeSO}_{4}$ 0.0001 . $\mathrm{pH}$ of the medium is set to 8 by the addition of Tris-HCl buffer (Jena and Rath, 2014). The suspension of each isolate was inoculated as much as $5 \%$ in the medium respectively. The cultures were incubated at room temperature with aeration using a rotary shaker at $130 \mathrm{rpm}$ for 5 days. Furthermore, the culture was centrifuged $6000 \mathrm{rpm}$ for $15 \mathrm{~min}$ (Qureshi et al., 2010). The supernatant was stored for enzyme activity analysis.

\section{e. Preparation of Acclimatization Medium}

Acclimatization medium is using $150 \mathrm{~mL}$ YMB (Yeast Malt Broth) with the addition of $\mathrm{Ca}_{3}\left(\mathrm{PO}_{4}\right) 25 \mathrm{~g} / \mathrm{L}$. Yeast isolates were inoculated on acclimatization medium aseptically and incubated until exponential phase $(\mu$ day) on a rotary shaker (Kathiresan et al., 2011).

\section{f. Influence of Incubation Time \\ Culture fromacclimation} medium was inoculated as much as $5 \%$ into Pikovskaya liquid medium. The 
cultures were incubated at room temperature using a rotary shaker at 130 rpm for 7 days. At each day, cultures were centrifuged (6000 rpm for $15 \mathrm{~min}$ ) (Qureshi et al., 2010). Test of enzyme activity was measured every day to determine the best incubation time. Best incubation time results will be used for next optimization stages.

\section{g. Influence of Combination of Phosphate Source and Temperature}

The test aimed to detect the appropriate substrates and temperature for the production of alkaline phosphatase.About $5 \mathrm{~g} / \mathrm{L}$ of $\mathrm{Ca}_{3}\left(\mathrm{PO}_{4}\right)_{2}$ and $\mathrm{KH}_{2} \mathrm{PO}_{4}$ asphosphatesourcewere added to Pikovskaya medium with incubation temperature were $29^{\circ} \mathrm{C}, 45^{\circ}$ $\mathrm{C}$ and $55^{\circ} \mathrm{C}$. About $5 \%$ culture from acclimation medium were inoculated into Pikovskaya liquid medium. The cultures were incubated at different temperature using incubator shaker 130 rpm with optimum incubation time obtained from the previous stage. Cultures were centrifuged $(6000 \mathrm{rpm}$ for $15 \mathrm{~min}$ at $4^{\circ} \mathrm{C}$ ) (Qureshi et al., 2010). The supernatant was stored for analysis enzyme activity.

\section{h. Alkaline Phosphatase Activity Test}

Measurement of the enzyme activity is done by mixing $1 \mathrm{~mL}$ substrate solution (2 mg / $\mathrm{mL}$ p-NPP in $1 \mathrm{M}$ Tris- $\mathrm{HCl}$ buffer solution at $\mathrm{pH} 10.0$ ) and $1 \mathrm{ml}$ of crude enzyme extract (supernatant) and incubated at $30^{\circ} \mathrm{C}$ for 10 minutes. The reaction was stopped by adding $0.05 \mathrm{ml}$ $4 \mathrm{M} \mathrm{NaOH}$ (Qureshi et al., 2010). Absorbance was measured using a UVVis spectrophotometer with $\lambda 410 \mathrm{~nm}$ (Jena and Rath, 2014). Control is $1 \mathrm{~mL}$ substrate and $1 \mathrm{~mL}$ of medium without inoculated yeasts with the same treatment. Activities per unit (U) are indicated in mol p-nitrophenol per minute (Jena and Rath, 2014). Measurement of the enzyme activity is done by interpolating the absorbance values on the p-nitrophenol standard curve then calculated by the following formula [2] where $U A$ is enzyme activity (unit/mL), $x$ is p-nitrophenol concentration $(\mu \mathrm{L}), v$ is volume of total reaction $(\mathrm{mL}), \quad t$ is reaction time (minute), $s$ is enzyme volume (mL) :

$$
U A=\frac{x . V}{t_{s} s}
$$

\section{RESULTS AND DISCUSSION}


The measurement of phosphat solubilization index showed that Solubilization Index (SI) of isolates were varied, there are 2 isolates that have higher SI when compared to other isolates (Figure 1). W1.1 isolate has SI value of 1.18, and G3.2 isolate has SI value of 1.15 . The ability of yeast isolates in phosphate solubilizationis indicated from the formation of clear zone on Pikovskaya solid medium. Pikovskaya Medium contain calcium phosphate $\left(\mathrm{Ca}_{3}\left(\mathrm{PO}_{4}\right)_{2}\right)$ as $\mathrm{P}$ source (Raharjo et al., 2007). Phosphate solubilization by microorganisms can be done by both chemically and biologically. The mechanism of chemically dissolving phosphate is a major phosphate solubilization mechanisms done by microorganisms. The microorganisms excrete a number of low molecular weight organic acids like oxalic, succinic, tartaric, citric, etc. (Ginting et al., 2006). Biological phosphate solubilization occurs because the microorganisms produce enzymes include phosphatase enzyme (Ginting et al., 2006). Two Isolates with the highest SI values will be further identified and tested the levels of soluble phosphate.

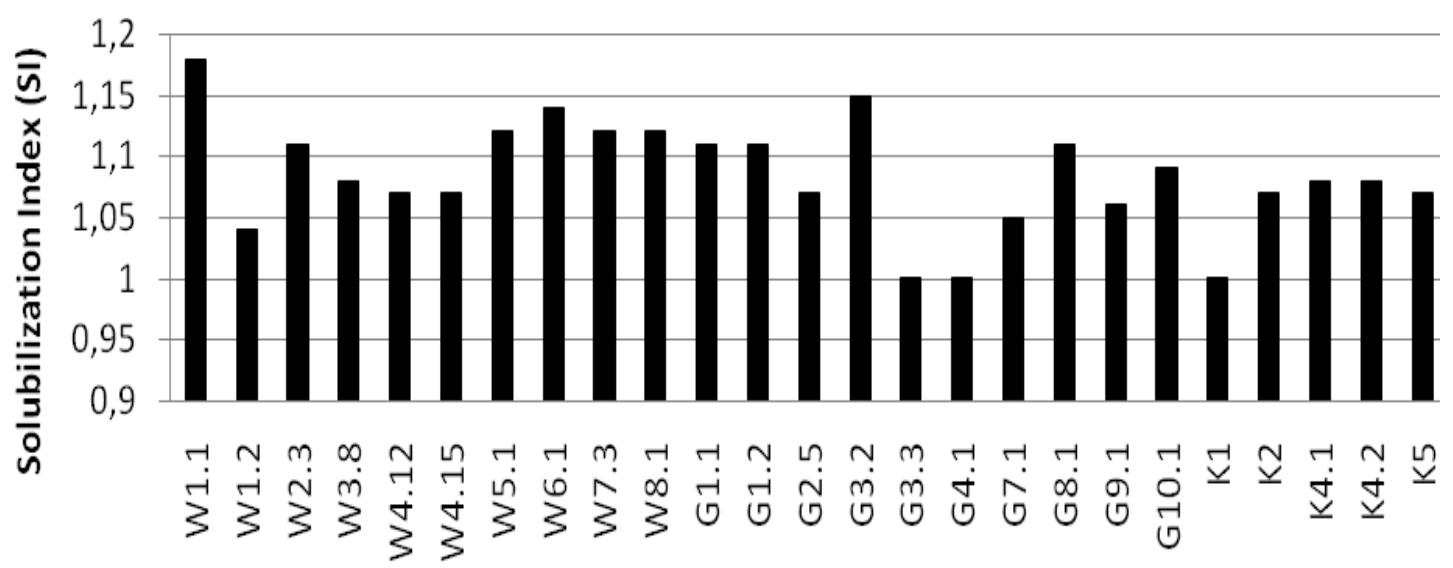

Isolates Code

Figure.1. Solubilization Index (SI) of yeast isolates

Yeast identificationis based on the"The yeasts a Taxonomic Study" (Kurtzman and Fell, 1998). The stages include macroscopic and microscopic observation, physiological or biochemical test, ascospores test and 
growth test in a liquid medium. The test results showed that W1.1and G3.2 isolates have similarities with the character of Candida. Some characters that strengthen the assumption that these isolates belong to the genus Candida are these isolates does not produce ascospore, forms pseudohypha with blastospores that appear in pseudohypha

branching.Vegetativereproduction with multilateral budding. Colonies are often circular with edges spread or full, forming convex elevations, has no carotenoid pigment,has an ovoid form of cells, are able to ferment some sugars, does not produce urease, forming a pellicle on the surface of the medium and white precipitate

The genus Candida is not found in the open sea, but manyof them are found in coastal waters and close to population centers where water is polluted by many domestic waste (Saavedra et al., 1995). Besides that,
Candida is well known as phosphate solubilizer (Kanti, 2006).

The measurement of soluble phosphate showed that the concentration increased during incubation time in line with the total colony of yeast (Figure 2 and Figure 3). Soluble phosphate concentration can deacreasein a certain incubation time ,because it was consumed by yeast. Soluble phosphate in the medium is used for oxidative respiration activity that plays a role in the transfer or glucose consumption into cells to generate ATP and biomass, that will enhance the growth (Raharjo et al., 2007). In addition, yeast isolates also produce large amounts of phosphate as an excess of nutrient supply that calculated as the concentration of dissolved phosphate. Soluble phosphate concentration of Candida W1.1 until 7 days of incubation time is $0.50 \mathrm{ppm}$ and soluble phosphate concentration of Candida G3.2 is $0.77 \quad \mathrm{ppm}$. 
Nur Hidayatul A., dkk. Akta Kimia Indonesia 4(1), 2019,

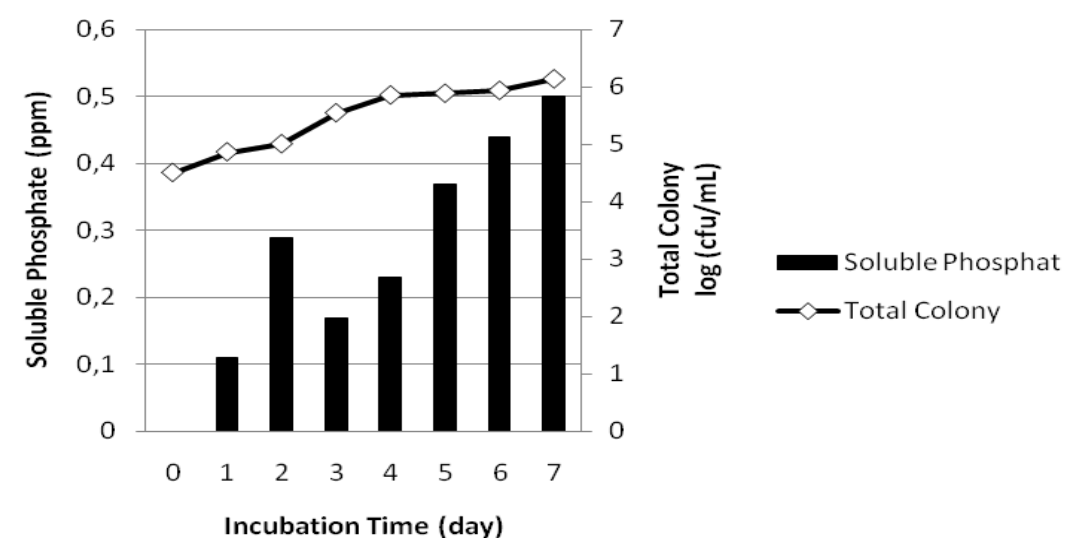

Figure 2. Soluble phosphate concentration and growth curve of CandidaW1.1

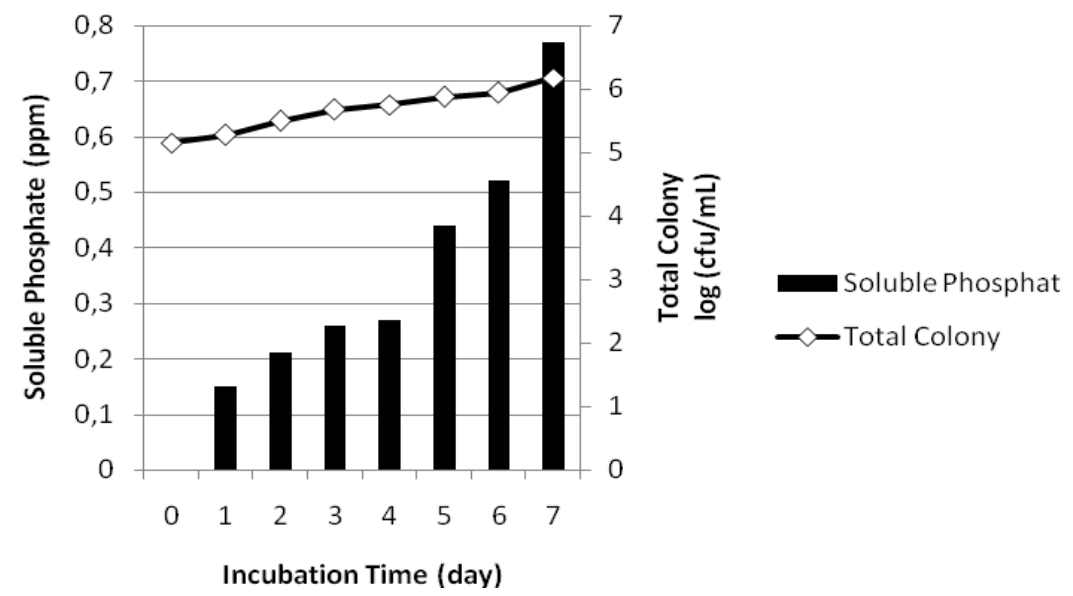

Figure 3. Soluble phosphate concentration and growth curve of Candida G3.2

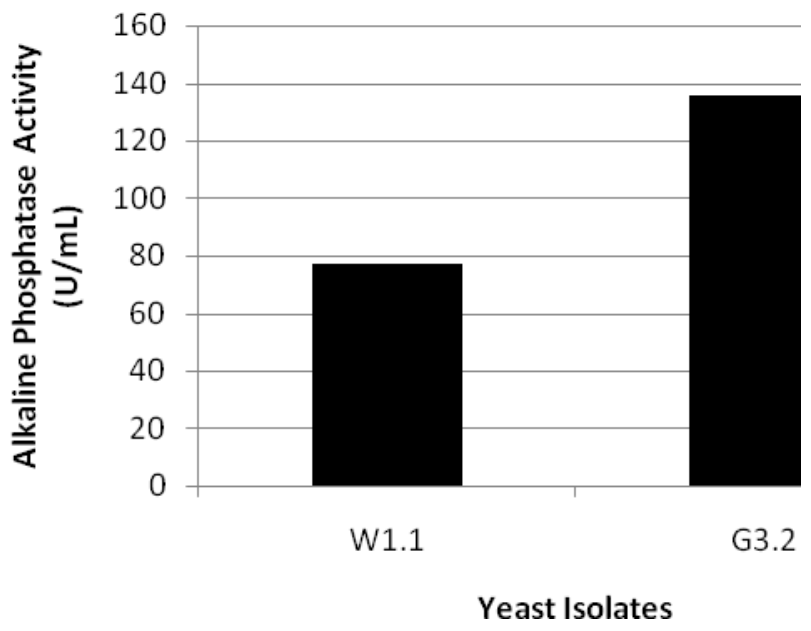

Figure 4. Alkaline Phosphatase Activity of Candida W1.1 and Candida G3.2 
Two of the best yeast isolates fromprevious test (Candida W1.1 and Candida G3.2) were tested its alkaline phosphatase activity. The test results showed Candida G3.2 enzyme activity higher than Candida W1.1. Candida G3.2 has enzyme activity of $135.8 \mathrm{U} /$ $\mathrm{mL}$ while Candida W1.1 has enzyme activity of $77 \mathrm{U} / \mathrm{mL}$ (Figure 4).

Differences in enzyme activity can occur, even in the same genus. This is due to the synthesis and activity of the enzyme that is influenced by genetic control and distribution of enzymes in the cell (Rogers, 2011). Inorganic phosphates also show the influence of the enzyme synthesisat different strains. One example of the Candida genus which is also known to have the potential to produce alkaline phosphatase is Candidautilis. Candidautilis showed alkaline phosphatase enzyme activity of $0.35 \mathrm{U} /$ mL (Alvarez et al., 1982). Alkaline phosphatase was found in Candida utilis, Candidaalbicans and Saccharomyces cerevisiae derived from intracellular namely the vacuole (Fernandez et al., 1981). Differences in enzyme activity were also influenced by cofactors (activator) in the form of alkaline phosphatase $\mathrm{Mg}^{2+}$ or $\mathrm{Zn}^{2+}$. Cofactor that is required depends on the strain of the microorganism used (Dick et al., 2011). The result (Figure 4) get Candida G3.2 had higher activity than Candida W1.1. Candida G3.2 will be optimized to produce the enzyme alkaline phosphatase.

Optimization of incubation time was conducted to determine the best extraction time during the alkaline phosphatase production. The optimum time is determined through the production of enzymes for 7 days with an interval of every 24 hours of extraction to determine the activity of alkaline phosphatase produced. Alkaline phosphatase activity increased with incubation time (Figure 5). The gradual increase in the production of enzymes occur from day-1 and the maximum production obtained on day 3 with the activity of $94.2 \mathrm{U} / \mathrm{mL}$, then seen a decrease in activity on day 4 to day 7. Day 3 can be assumed to be the beginning of the stationary phase. The increased of enzyme activity can be caused by the high metabolic activity of yeast cells in a cell-division and the 
synthesis of the enzyme. The secretion of alkaline phosphatase will be increasing along with the number of cells, This is consistent with the statement (Das et al., 2013) that the enzyme secretion depends on the number of cells and the specific microorganism growth phase. The decrease in enzyme activity occurs on day 3 to day 7 . This could be caused by the maximum production of the enzyme, there is a production of other products and a decrease in the nutrient medium.

Optimization of the influence of temperature variation and phosphate sources used to obtain optimal temperature and phosphate source that is suitable for the production of alkaline phosphatase. This test was done by incubating the culture at different temperatures $\left(29{ }^{\circ} \mathrm{C}, 45^{\circ} \mathrm{C}\right.$ and $\left.55^{\circ} \mathrm{C}\right)$ using a Pikovskaya medium with phosphate modification. Incubation was performed for 3 days which is obtained from the previous stage. The test results statistically using Two-WayANOVA, the result showed that temperature affects the activity of alkaline phosphatase significantly. While these types of phosphate source did not show a significant difference, but at a temperature of $29{ }^{\circ} \mathrm{C}$ and $45{ }^{\circ} \mathrm{C}$ the phosphate source of $\mathrm{Ca}_{3}\left(\mathrm{PO}_{4}\right)_{2}$ higher than $\mathrm{KH}_{2} \mathrm{PO}_{4}$ (Figure 6). The optimal temperature for the production of alkaline phosphatase is at a temperature of $29{ }^{\circ} \mathrm{C}$ with the highest activity on both substrates of $97.8 \mathrm{U} / \mathrm{mL}$ in $\mathrm{Ca}_{3}\left(\mathrm{PO}_{4}\right)_{2}$ and $93 \mathrm{U} / \mathrm{mL}$ in $\mathrm{KH}_{2} \mathrm{PO}_{4}$. Alkaline phosphatase enzymes can be produced at a temperature range of 29 ${ }^{\circ} \mathrm{C}-55{ }^{\circ} \mathrm{C}$. These results similar to some psychrophilic bacteria andE.coli that has an optimum temperature at $30^{\circ} \mathrm{C}$ $40{ }^{\circ} \mathrm{C}$. Higher temperatures could increase the kinetic energy of the molecules that break down the active bond on the amino group so that the enzyme is denatured (Mahesh, 2010). Temperature plays an important role in producing enzymes of microorganisms because it affects the solubility of oxygen in the nutrient medium, increasing the kinetic energy of the molecules and the speed of enzymatic reactions inside the cell, microorganism growth, and metabolism (Omran and Qaddoori, 2014).Temperature can also affect the sensitivity of yeast to produce 
the product concentration, growth rate, fermentation rate, viability, the length of the lag phase and membrane function (Jackson, 2000). Differences in enzyme activity can also be caused by the optimum growth of Candida genus at a temperature of $20-38{ }^{\circ} \mathrm{C}$ (Komariah and Sjam, 2012).

Among the phosphate sources, $\mathrm{Ca}_{3}\left(\mathrm{PO}_{4}\right)_{2}$ was found suitable for producing alkaline phosphatase (Priya et al., 2014). This is due to inorganic phosphate in alkaline conditions found in the environment in the form of
$\mathrm{Ca}_{3}\left(\mathrm{PO}_{4}\right)_{2}$ (Kapri and Tewari, 2010). Besides that, enzymes have the active site. The active site is a specific part of the amino acid side chains that can bind one molecule or several types of molecules when a chemical reaction takes place. Most enzymes show a high degree of specificity for binding specific substrate and catalyze specific reactions to produce specific products (Mahesh et al., 2015). This causes $\mathrm{Ca}_{3}\left(\mathrm{PO}_{4}\right)_{2}$ suitable for the production of alkaline phosphatase compared to other phosphate sources.

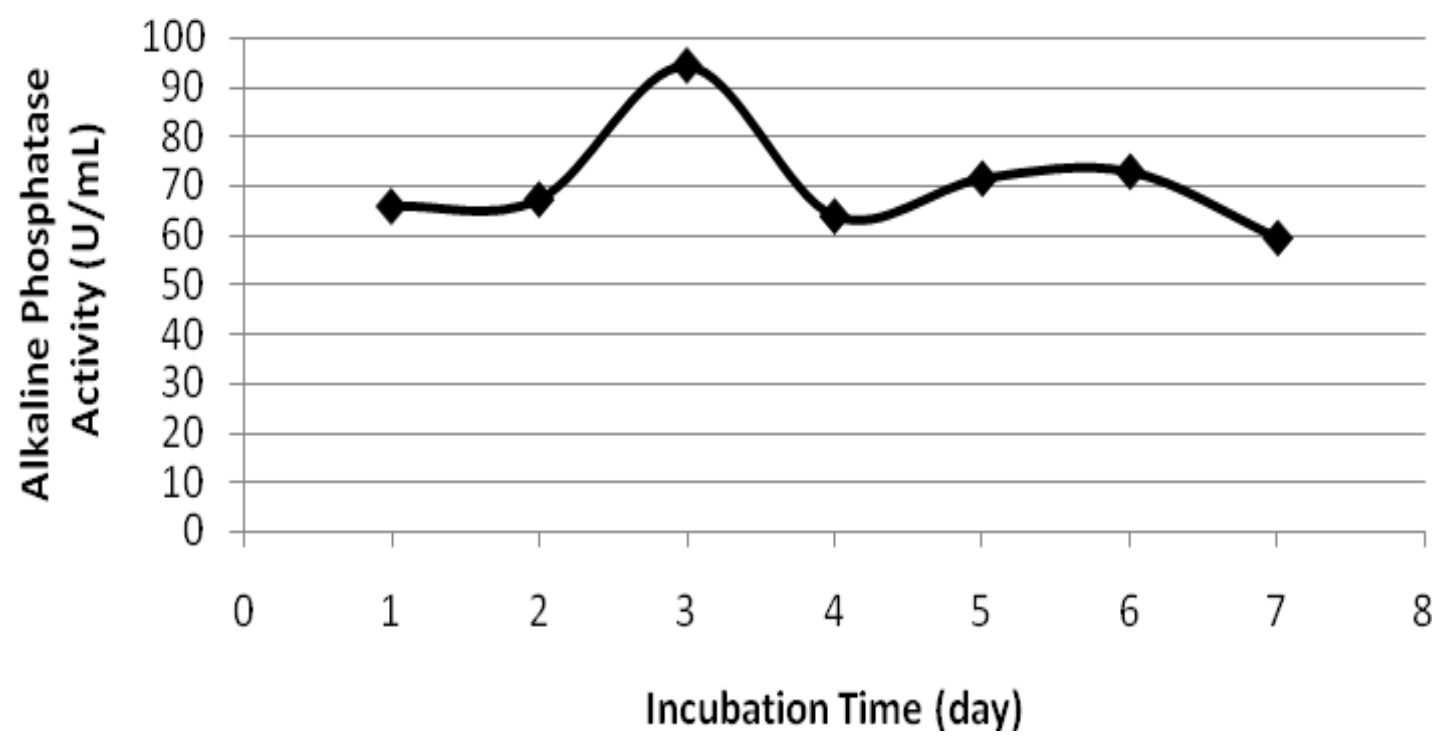

Figure 5. The influence of incubation time on alkaline phosphatase by Candida G3.2 


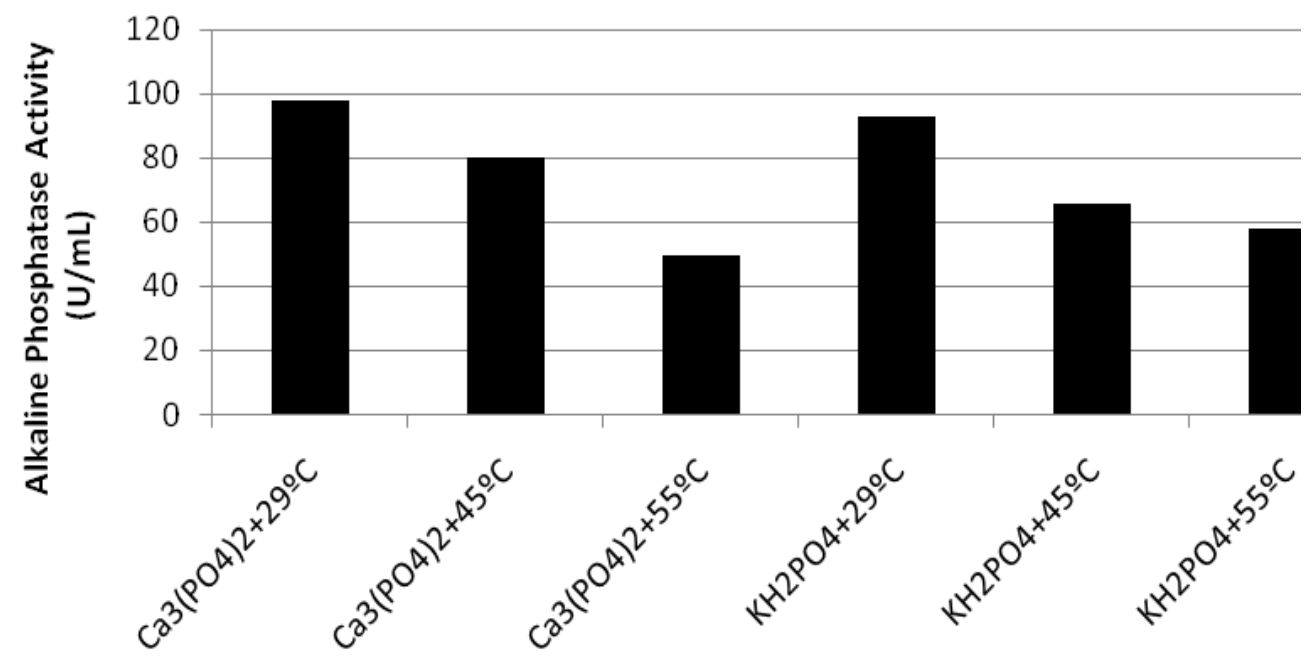

Combination of Phosphate Source and Temperature

Figure 6. The influence of temperature and phosphate source on alkaline phosphatase activity by Candida G3.2

\section{CONCLUSION}

The result showed that isolates with the highest phosphate solubilization index were W1.1 and G3.2. The value of W1.1 was 1.18 and the value of G3.2 was 1.15. Yeast with theability to solubilize phosphate was assumed of Candidagenus.Candida W1.1 and Candida G3.2 respectively produce soluble phosphate in a concentration of $0.50 \mathrm{ppm}$ at the 7 th day and in a concentration of $0.77 \mathrm{ppmat}$ the 7 th day. Candida G3.2 has higher enzyme activity than Candida W1.1. Candida G3.2 has optimal production at the time of incubation for 3 days, with combination of temperature $29{ }^{\circ} \mathrm{C}$ and the source of phosphate used $\mathrm{Ca}_{3}(\mathrm{PO} 4)_{2}$ with the value of enzyme activity was $97.8 \mathrm{U} / \mathrm{mL}$

\section{ACKNOWLEDGMENT}

This work was carried out as part of "Terobosan Baru :Yeast Layak Menjadi Biofertilizer Komersial". This research was supported by grants from Penelitian Pemula 2016 awarded by Dana PNBP ITS 2015.

\section{REFERENCES}

Alami,N.H. and Shovitri,M. (2015).

Studi Lanjut Marine Yeast sebagai Biofertilizer Komersial" Laporan Akhir Penelitian Pemula. Jurusan 
Biologi Fakultas Matematika dan

Ilmu Pengetahuan Alam Institut

Teknologi Sepuluh Nopember.

Surabaya

Alvarez,N.G., $\quad$ Rendueles,M.P.S,

Fernandez,P. And Gascon,S.

(1982). Regulation of Alkaline

Phosphatase Synthesis in Candida

Utilis, Journal of General

Microbiology, Vol 128, 1217-12

Baranov, K., Volkova, O., Chikaev, N.,

Mechetina, L., Laktionov, P.,

Najakshin, A., and Taranin, A.

(2008). A Direct Antigen-Binding

Assay for Detection of Antibodies

Against Native Epitopes using

Alkaline Phosphatase-Tagged

Proteins. J. Immunol Methods, Vol $332,73-81$.

Chi, Z.M., Chi, Z., Zhang, T.,. Liu, G.L, Li, J., and Wang, X.H. (2009). Production, characterization and gene cloning of the extracellular enzymes from the marine-derived yeasts and their potential applications, Biotechnol,Vol 3, 236-355

Das,A., Paul,T., Halder,S.K., Maity,C., Mohapatra,P.K.D., Pati,B. R., Mondal, K.C. (2013). Study on Regulation of Growth and Biosynthesis of Cellulolytic Enzymes from Newly Isolated Aspergillus fumigatus ABK9. Journal of Microbiology, Vol $62(1), 31-43$

Dick,C.F., Dos-Santos,A.L.A., and Fernandez, J.R.M. (2011). Inorganic Phosphate as an Important Regulator of Phosphatase. Enzyme Research, Vol 7

Fernandes, J., Amorim, R., Azevedo, I., and Martins, M.J. (2008). In Vitro Modulation of Alkaline Phosphatase Activity of 
Saccharomyces cerevisiae Grown in Low or High Phosphate Medium. Brazilian J Medical and Biol, Res Vol 41, 41-46.

Fernandez,M.P., $\quad$ Gascon,S., $\quad$ and Schwencke,J. (1981). Some Enzymatic Properties of Vacuolar Alkaline Phosphatase from Yeast. Current Microbiology, Vol6, 121126

Ginting, R.C.B., Saraswati, R., and Husen, E. (2006) . Pupuk Organik dan Pupuk Hayati: Mikroorganisme Pelarut Fosfat. Jakarta: Balai Besar Litbang Sumber Daya Lahan Pertanian Badan Penelitian dan Pengembangan Pertanian.

Guo,J., Gao,M., Song,Y., Lin,L., Zhao,K., Tian,T., Liu,D., Zhu,Z., and Yang,C.J. (2018). An Allosteric-Probe for Detection of Alkaline Phosphatase Activity and
Its Application in Immunoassay. Analytical Chemistry, a section of the journal Frontiers in Chemistry, Volume 6 | Article 618 Holander, V.P. (1971). Acid Phosphatases, In: Enzymes. P.D. Boyer (Ed.). New York : Academic Press.Jackson,R.S. (2000). Wine Science. USA: Academic Press.

Jena, S.K. and Rath, C.C. (2013). Optimization of Culture Conditions of Phosphate Solubilizing Activity of Bacterial sp.Isolated from Similipal Biosphere Reserve in Solid-State Cultivation by Response Surface Methodology. International Journal of Current Microbiology and Applied Sciences, 2(5): 47-59

Jena,S.K. and Rath,C.C. (2014). Effect of Environmental and Nutritional Conditions on Phosphatase Activity of Aspergillus awamori. Current 
Research in Environmental \& Applied Mycology, Vol 4, 45-56.

Kandasamy, K., Alikunhi, N., Subramanian, M. (2012).Yeasts in marine and estuarine environments. Journal of Yeast and Fungal Research,Vol 6, 74-82.

Kanti, A. (2006). Marga Candida, Khamir Tanah Pelarut Posfat yang Diisolasi dari Tanah Kebun Biologi Wamena, Papua. Biodiversitas, 7(2): 105-108

Kapri,A. and Tewari,L. (2010). Phosphate Solubilization Potential and Phosphatase Activity of Rhizospheric Trichoderma spp, Brazilian Journal of Microbiology. Kathiresan,K., $\quad$ Saravanakumar,K., Senthilraja,P. (2011). Bioethanol Production by Marine Yeast Isolated from Coastal Mangrove Sediment. Journal of Int. Multidiscip Res, Vol1, 19-24.
Komariah and Sjam,R. (2012).

Kolonisasi Candida dalam Rongga Mulut," Majalah Kedokteran FK $U I$, (jan-mar).

Kurtzman, C.P. and Fell, J.W. (1998).

The Yeast: A Taxonomic Study. Amsterdam: Elsevier Science B.V.

Kutty, S. N. and Philip, R. (2008). Marine yeasts - a Review. Yeast, 25: 465-483.

Lambertz,D., Carillo,C.D., Adam,G,K., Manninger, P., Burton,W.B. (2014). GeneSippr: A Rapid Whole-Genome Approach for the Identification and Characterization of Foodborne Pathogens such as Priority Shiga Toxigenic Escherichia coli, Journal Plos One. Mahesh, $\quad$ M., $\quad$ Neha,G., Somashekar,R.,Rajesh,T.S., and Puttaiah,E.T. (2010). Isolation and Characterization of Extracellular Thermostable Alkaline Phosphatase 
Enzyme from Bacillus spp. Production of Enzymes by Fungi. International Journal Applied Dynamics Biochemistry, Process Biology and Pharmatceutical Biotecnology and Molecular Technology Vol 1, 21-33. Biology, Vol 2, 14-18.

Mahesh,M., Somashekar,R., Bagchi,P., Omran,R., and Qaddoori,A. (2014). and Puttaiah,E.T. (2015). Optimize Environmental Optimization for The Production of Production Conditions of Extracellular Alkaline Phosphatase from Proteus mirabilis. Journal Bioprocess Biotech, Vol 5, 3.

Muginova, S.V., Zhavoronkova,A.M., Polyakov, A.E., and (2007).

Shekhovtsova,T.N.

Application of Alkaline

Phosphatases from Different

Sources in Pharmaceutical and

Clinical Analysis for the

Determination of Their Cofactors;

Zinc and magnesium Ions. Analytical Science, Vol 23, 357363.

Norouzian, D. (2008). Effect of Different Factors on Fermentative Extracellular Alkaline Phosphatase from Bacillus sp. I. World Journal of Pharmaceutical Research, Vol 3, 01-11.

Priya,D., Kumar,D.J.M., and Kalaichelvan,P.T. (2014). Optimization and Production of Extracellular Alkaline Phosphatase from Bacillus megaterium. International Journal of ChemTech Research, Vol 6, 4251-4258.

Qureshi,A.S., Dahot,M.U., and Panhwar, S.I. (2010). Biosysnthesis of Alkaline Phosphatase by Escherichia coli Efrl 13 in Submerged Fermentation. World 
Applied Sciences Journal, Vol 8, $50-56$.

Raharjo, B., Suprihadi, A., and Agustina, D.K. (2007). Pelarutan Fosfat Anorganik oleh Kultur Campur Jamur Pelarut Fosfat Secara In Vitro. Jurnal Sains \& Matematika (JSM), 15(2): 45-54.

Rin, M., Pozidis, C., Mavromatis, K., Tzanodaskalaki, M., Kokkinidis, M., and Bouriotis, V. (2000). Alkaline phosphatase from the Antarctic Strain TAB5. Properties and psychrophilic adaptations. Europian Journal of Biochemistry, Vol 267, 1230-1238. Rogers,K. (2011). The Componenets of Life From Nucleic Acids to Carbohydrates, $\quad$ Britannica Educational Publishing: New York. Saavedra, N.Y.H., Saavedra, D.H., and Ochoa,J.L.(1995). $\quad$ Factors
Affecting the Distribution of the Genus Candida (Berkhout) Along the West Coast of Baja California Sur, Mexico. Appl. Microbiol, 18: 109-112.

Saraswati, R., Husen, E. and Simanungkalit, R.D.M. (2007). Metode Analisis Biologi Tanah. Bogor: Balai Besar Penelitian dan Pengembangan Sumberdaya Lahan Pertanian.

Sasajima, Y., Iwasaki, R., Tsumoto, K., Kumagai, I., Ihara, M., and Ueda, H. (2010). Expression of Antibody Variable Region-Human Alkaline Phosphatase Fusion Proteins in Mammalian Cells. Journal Immunological Methods, Vol 361, 57-63.

Sigma-Aldrich. (2013). Product Information [Online]. Available : www.sigmaaldrich.com 